\title{
Salicylic Acid, Phosphorous Acid and Fungicide Sumi 8 Effects on Polyphenol Oxidases Activities and Cassava Resistance to Anthracnose
}

\author{
Seu Jonathan Gogbeu ${ }^{1, ~ *}$, Koffi Mathurin Okoma ${ }^{2}$, Koua Serge Beranger N'Goran ${ }^{3}$, \\ Dénézon Odette Dogbo ${ }^{4}$ \\ ${ }^{1}$ Laboratory of Plant Physiology and Pathology, Department of Agroforestry, University Jean Lorougnon Guede, Daloa, Cote d'Ivoire \\ ${ }^{2}$ Central Laboratory of Biotechnology, National Agronomic Research Centre (CNRA), Abidjan, Cote d'Ivoire \\ ${ }^{3}$ National Centre of Floristic, Department of Biosciences, University Felix Houphouet-Boigny, Abidjan, Cote d'Ivoire \\ ${ }^{4}$ Laboratory of Biology and Plant Production Improvement, Department of Sciences and Nature, University Nangui-Abrogoua, Abidjan, Cote \\ d'Ivoire
}

\section{Email address:}

jgogbeu@yahoo.fr (S. J. Gogbeu), okomakoffi@yahoo.fr (K. M. Okoma), kouaberanger@yahoo.fr (K. S. B. N'Goran), denezon@yahoo.fr (D. O. Dogbo)

\section{To cite this article:}

Seu Jonathan Gogbeu, Koffi Mathurin Okoma, Koua Serge Beranger N'Goran, Dénézon Odette Dogbo. Salicylic Acid, Phosphorous Acid and Fungicide Sumi 8 Effects on Polyphenol Oxidases Activities and Cassava Resistance to Anthracnose. American Journal of Agriculture and Forestry. Vol. 3, No. 3, 2015, pp. 109-115. doi: 10.11648/j.ajaf.20150303.18

\begin{abstract}
In Côte d'Ivoire, cassava contributes enormously to improve food security of population by increasing national production and financial resources of vulnerable households. But, plant is attacked by several diseases including anthracnose. This study was done to improve its resistance to anthracnose by stimulating its natural defense following treatment plants with salicylic acid, phosphorous acid and fungicide Sumi 8 as elicitors. Polyphenol oxidases were chosen as resistance marker. Results showed that in the three cultivars (yacé, TMS30572 and I88/00158), yacé was more susceptible to anthracnose (p<0.05; $\mathrm{F}=6.83$ ). After treatments, cassava resistance against anthracnose has been improved. Polyphenol oxidases activities were more stimulated in presence of elicitor's phosphorous acid and salicylic acid. Native-PAGE of polyphenol oxidases revealed 11 isoenzymes including 7 new isoenzymes detected in elicited plants, treated plants contaminated or uncontaminated by Colletotrichum gloeosporioides, pathogen of anthracnose. Recent isoenzymes were specific for each cultivar. Their appearance was correlated with plant resistance to $C$. gloeosporioïdes. In these plants, in particular those germinated directly in elicitation medium, anthracnose symptoms were lessened. These elicitors were thus induced and/or stimulated cassava defense especially polyphenol oxidases activities.
\end{abstract}

Keywords: Anthracnose, Cassava, Elicitors, Polyphenol Oxidases

\section{Introduction}

Polyphenol oxidases [PPO (EC. 1.14.18.1 and EC. 1.10.3.2)] are plant enzymes using molecular oxygen to oxidize phenolic compounds to quinones [1]. These reactions commonly contribute to tissue browning of fruits and vegetables, and consequently to the deterioration of consumer products quality. However, according to Mayer [2], Constabel and Barbehenn [3], role of PPO plants is associated with the defense against pathogenic microorganisms. In fact, role attributed to PPO is related to modification of endogenous phenolic compounds by these enzymes, in particular quinones that are toxic to pathogenic microorganisms [4] [5]. In tomato (Solanum lycopersicum L) plants infected by Fusarium oxysporium, PPO activities increased both in susceptible and resistant plants [6]. Other studies have indicated that induction of PPO activities could be caused by elicitors [7] [8]. Thus, in cassava processing plants by salicylic acid and phosphorous acid, similar responses were evoked [9] [10]. Therefore, Flurkey and Inlow [11] show that induction of PPO genes in response to plant hormones clearly suggests that these enzymes are released during plant resistance. Based on these results, PPO can be mentioned as marker for plant defenses. In order to establish a link between production of PPO under effect of 
elicitor's salicylic acid, phosphorous acid or fungicide Sumi 8 and resistance of cassava to anthracnose, this study was conducted. Indeed, cassava in Côte d'Ivoire contributes enormously to improve food security of populations by increasing national production and financial resources of vulnerable households. With production estimated at over 2 million tonne, cassava is the second food after yams [12]. But despite these production efforts, cassava is prone to many diseases including anthracnose [13]. However, in developing countries such as Côte d'Ivoire, application of fungicides is only means of protection of plants against diseases. But, the misuse of these products leads to the induction of long-term pathogenic microorganisms resistance and environmental damage through the toxic residues accumulation [14] [15], which could act negatively on the health of consumers. Natural defense induction by elicitor application then appears as a means to fight against pathogenic microorganisms and especially environment preservation. Or in cassava, work on PPO activities induction and plant resistance to pathogens has not been discussed in the literature.

\section{Materials and Methods}

\subsection{Plant and Experimental}

Yacé, TMS30572 and I88/00158 plants aged of six week were used for experimentation. Yacé is a traditional cultivar commonly grown in Côte d'Ivoire. By cons, TMS30572 cultivar was introduced by International Institute of Tropical Agriculture (IITA, Nigeria). As for I88/00158 cultivar, it has been improved by National Centre of Agricultural Research (CNRA, Côte d'Ivoire) and now popularized as Bocou2.

Cassava plants were obtained from hydroponic according to Gogbeu et al [10] method. Cuttings sterilized with alcohol $70 \%(\mathrm{v} / \mathrm{v})$ were placed in two germination medium: nutrient medium containing phosphorus $\left(\mathrm{P}_{2} \mathrm{O}_{3}\right)$ and dolomite $\left(\mathrm{CaMg}\left(\mathrm{CO}_{3}\right)_{2}\right)$ at dose of $80 \mathrm{mg} \mathrm{L}^{-1}$ each, namely $\mathrm{M}_{0}$ medium, and $\mathrm{M}_{0}$ medium supplemented with $1 \mathrm{mM}$ of salicylic acid (SA, SIGMA), $1 \mathrm{mM}$ of phosphorous acid (PA, SIGMA) or $0.5 \mathrm{mM}$ of fungicide Sumi 8 (Syngeta Society) qualified $\mathrm{M}_{\mathrm{SA}}$, $\mathrm{M}_{\mathrm{PA}}$ and $\mathrm{M}_{\mathrm{S}}$ medium respectively. For each cultivar, plants were divided into two blocks according to contamination mode: block uncontaminated plants [plants from $\mathrm{M}_{0}$ medium (3 plants) and plants from $\mathrm{M}_{\mathrm{SA}}, \mathrm{M}_{\mathrm{PA}}$ and $\mathrm{M}_{\mathrm{S}}$ medium (3 plants / medium) that have not been contaminated with $C$. gloeosporioïdes] and block contaminated plants [plants from $\mathrm{M}_{0}$ medium ( 3 plants / contamination time), plants from $\mathrm{M}_{\mathrm{SA}}$, $\mathrm{M}_{\mathrm{PA}}$ and $\mathrm{M}_{\mathrm{S}}$ medium (3 plants / medium /contamination time) and plants from $\mathrm{M}_{0}$ medium then transferred to $\mathrm{M}_{\mathrm{SA}}, \mathrm{M}_{\mathrm{PA}}$ or $\mathrm{M}_{\mathrm{S}}$ medium (3 plants /medium/contamination time) infected with C. gloeosporioïdes].

\subsection{Estimation of Pathogen Propagation Speed}

Pathogen was isolated from stems of cassava diseased plants. These stems were disinfected with alcohol $70 \%$ (v/v) and quickly flamed under a laminar flow hood. Samples of $0.5 \mathrm{~cm}$ collected around necrotic area were placed in Petri dishes containing PDA medium previously prepared. After 3 days of incubation at $28{ }^{\circ} \mathrm{C}$ in dark, fruiting bodies were collected using a sterile needle and transplanted into new PDA medium. After 5 to 6 subculture, pure cultures of fungi were obtained and stored at $4{ }^{\circ} \mathrm{C}$ in refrigerator. Plant contamination was performed according to Makambila [16] method. Stems of selected plants were pricked in part not yet lignified [2/3 upper stem] using a thin heated to red needle. On the $3^{\text {rd }}$ day after injection, fungi (mycelial and conidia) were given in capsule form $\left(1 \mathrm{~mm}^{2}\right)$ collected by scraping on culture medium. After various treatments, room humidity was maintained by daily watering. Distance traveled by fungi within stem was determined at $12^{\text {th }}$ Day after plant contamination. To do this, contaminated stems were cracked in length and distance traveled by pathogen within stem was measured using a ruler [17].

\subsection{Extraction and Assay of Polyphenol Oxidases Activities}

Polyphenol oxidases were extracted using Gogbeu et al [18] method with some modification. Extraction buffer of PPO varied according to cultivar. There are $0.2 \mathrm{M}$ sodium phosphate buffer $\mathrm{pH} 5$ [PPO extracted from $188 / 00158$ $(i \mathrm{PPO})]$ and $\mathrm{pH} 6$ [PPO extracted from $\left.T M S 30572\left(t_{30} \mathrm{PPO}\right)\right]$, and $0.2 \mathrm{M}$ Tris- $\mathrm{HCl} \mathrm{pH} 7.5$ [PPO extracted from yacé ( $y$ PPO)]. To do this, one $\mathrm{g}$ of limbs was ground in $10 \mathrm{~mL}$ of extraction buffer supplemented with Triton X-100 (100/1, v/v) and the whole was centrifuged at $15000 \mathrm{x}$ g for $30 \mathrm{~min}$ at $4{ }^{\circ} \mathrm{C}$. Supernatant was recovered and pellet was taken up in 5 $\mathrm{mL}$ of extraction buffer and then ground and centrifuged as before. Combined supernatants formed extracted PPO.

Enzyme activity was assayed in $3 \mathrm{~mL}$ of reaction mixture, consisting of $50 \mu \mathrm{L}$ of enzymatic extract and $100 \mathrm{mM}$ of dopamine [ $y \mathrm{PPO}$ and $i \mathrm{PPO}$ or pyrocatechol $\left[t_{30} \mathrm{PPO}\right.$. After 5 min incubation at $30{ }^{\circ} \mathrm{C}\left(t_{30} \mathrm{PPO}\right), 35^{\circ} \mathrm{C}(y \mathrm{PPO})$ and $40{ }^{\circ} \mathrm{C}$ $(i \mathrm{PPO})$, reaction mixtures were cooled in a controlled bath regulated at $4{ }^{\circ} \mathrm{C}$. PPO activities were determined by measuring absorbance (spectrophotometer, Milton Roy) at $420 \mathrm{~nm}\left(y \mathrm{PPO}, t_{30} \mathrm{PPO}\right)$ or $470 \mathrm{~nm}(i \mathrm{PPO})$ against a control containing no substrate. PPO activities were expressed in absorbance per minute per milligram of protein $(\Delta \mathrm{DO} / \mathrm{min} / \mathrm{mg}$ prot.). Maximum stimulation of PPO activities was expressed as difference between high enzyme activity and PPO activities extracted from plants from $\mathrm{M}_{0}$ medium.

\subsection{Native-PAGE of Polyphenol Oxidases}

Polyacrylamide gel electrophoresis was performed according to Laemmli [19] for separating PPO isoenzymes of cassava leaves in nondenaturing conditions. It was performed with a discontinuous buffer system using 4\% stacking gel and $10 \%$ resolving gel. Resolving gel was prepared by mixing $33.3 \mathrm{~mL}$ of acrylamide / bis-acrylamide (30\% T, 2.6\% C) to $40.2 \mathrm{~mL}$ of distilled water and $25 \mathrm{~mL}$ of $1.5 \mathrm{M}$ Tris$\mathrm{HCl}$ buffer $\mathrm{pH}$ 8.8. After $15 \mathrm{~min}, 500 \mu \mathrm{L}$ of $10 \%(\mathrm{w} / \mathrm{v})$ ammonium persulphate and $50 \mu \mathrm{L}$ of TEMED were added. Whole was mixed and poured between two glass plates, separated on both sides by spacers which assembly is placed 
on a support. Gel is covered with $1 \mathrm{~mL}$ of n-butanol. After 90 min of polymerization, n-butanol is rinsed thoroughly and $4 \%$ stacking gel is poured above resolving gel. This gel was prepared by mixing $1.3 \mathrm{~mL}$ of acrylamide / bis-acrylamide $(30 \% \mathrm{~T}, 2.67 \% \mathrm{C})$ to $6.1 \mathrm{~mL}$ of distilled water, $2.5 \mathrm{~mL}$ of 0.5 M Tris- $\mathrm{HCl}$ buffer $\mathrm{pH} 6.8,50 \mu \mathrm{L}$ of $10 \%$ (w/v) ammonium persulphate and $10 \mu \mathrm{L}$ of TEMED. Enzyme samples $(32 \mu \mathrm{L}$ enzyme extract and $8 \mu \mathrm{L}$ of $0.1 \%$ bromophenol blue) were applied to well spaces in stacking gel. Migration was performed at $18^{\circ} \mathrm{C}$. It was carried out first at constant current of $9.8 \mathrm{~mA}$ and then increased to $12 \mathrm{~mA}$ and it was stopped when bromophenol blue reached the bottom of resolving gel. Revelation of PPO was to put essentially highlight functional proteins by $\mathrm{Wu}$ and Duan [20] method. Thus, after migration, gel removed from plates was immersed for $120 \mathrm{~min}$ into solution containing $0.2 \mathrm{M}$ sodium phosphate buffer $\mathrm{pH} 5$ and $100 \mathrm{mM}$ dopamine for $i \mathrm{PPO} ; 0.2 \mathrm{M}$ sodium phosphate buffer pH 6 and $100 \mathrm{mM}$ pyrocatechol for $t_{30} \mathrm{PPO}$ or $0.2 \mathrm{M}$ Tris- $\mathrm{HCl}$ $\mathrm{pH} 7.5$ and $100 \mathrm{M}$ dopamine for $y$ PPO. Isoenzyme bands were photographed. Calculated frontal reports were classified isoenzymes.

\subsection{Amount of Protein}

Amount of protein was determined using dye-binding method of Bradford [21], with bovine albumin as the standard, measuring optical density at $595 \mathrm{~nm}$.

\subsection{Statistical Analysis of Data}

SPSS version 11.5 software was used to compare data. Analysis of variance (ANOVA) with one and two classification criteria was made. Difference between means at 95\% confidence level calculated using Duncan test.

\section{Results and Discussion}

\subsection{Colletotrichum Gloeosporioides Propagation Speed Within Cassava Stems}

Analysis of table 1 shows that average length of fungi propagation in control plants (PC) varied among cultivars ( $p$ $<0.05 ; \mathrm{F}=7.13)$. It was $3.63 ; 3.03$ and $1.40 \mathrm{~cm}$ respectively for yacé, I88/00158 and TMS30572. When these plants were elicited and contaminated (PE), pathogen growth within stem was delayed in yacé. By cons in TMS30572 and I88/00158, speed was slightly important [PA $(1.17 \mathrm{~cm})$ and Sumi $8(1.50$ $\mathrm{cm})$ for TMS30572; SA $(3 \mathrm{~cm})$ and PA $(2.53 \mathrm{~cm})$ for I88/00158]. In contrast, plants (PT) obtained from cuttings directly into elicitation medium prevented pathogen growth. Indeed, apart from I88/00158 where C. gloeosporioides progression speed was important for plants from elicitation PA ( $\mathrm{F}=14.29, \mathrm{P}<0.001)$ medium, first symptoms observed at $5^{\text {th }}$ Day could not develop (Table 1). These results suggest that all cultivars are susceptible to anthracnose. In terms of progression speed of pathogen within stem, yacé would be more susceptible than I88/00158 and TMS30572. But after elicitation of yacé plants, pathogen growth was slower. So, we can say SA, PA and Sumi 8 helped improve cassava defense system against anthracnose. These phenomena were more pronounced with results recorded in PT. Indeed, in the latter, pathogen propagation speed was significantly reduced; this would correspond to fungi arrest mechanism in migration process. Latter was confined at inoculation site. This result could be explained by the fact that these plants had already set up their defense system after different treatments. Similar results were obtained by several authors [22] [23]. They advocated pretreatment method with elicitors in plants as a means to fight against plant diseases. In bean (Vigna mungo), pretreatment of plant with SA 24 hours before virus (urdbean leaf crinke virus) inoculation, has helped reduce disease symptoms while contaminated plants at same time to SA treatment developed significant symptoms [23]. Our results indicate that in cassava, a long period of pretreatment may be recommended to reduce anthracnose impact.

\subsection{Native-PAGE of Polyphenol Oxidases}

In order to identify all functional PPO isoenzymes in cassava leaves, native-PAGE was performed. This showed existence of 4 isoenzymes constituent rated $\mathrm{PPO}_{1}, \mathrm{PPO}_{2}$, $\mathrm{PPO}_{3}$ and $\mathrm{PPO}_{4}$ in studied cultivars. When plants were stressed (elicitation and / or inoculation with pathogen), 7 new forms were induced: $\mathrm{PPO}_{5}, \mathrm{PPO}_{6}, \mathrm{PPO}_{7}, \mathrm{PPO}_{8}, \mathrm{PPO}_{9}$, $\mathrm{PPO}_{10}$ and $\mathrm{PPO}_{11}$. Indeed, in yacé, 4 distinct bands representing different forms of PPO were revealed (Figure 1). Among these isoenzymes, $\mathrm{PPO}_{1}$ and $\mathrm{PPO}_{3}$ were constantly present whatever treatment undergone by plants. In contrast, in PC contaminated, at $12^{\text {th }}$ Day (line 3) and plants elicited with salicylic acid (SA) (lines 4 and 5) and phosphorous acid (PA) (lines 6 and 7), $\mathrm{PPO}_{7}$ has been detected. In yacé plant treated, $\mathrm{PPO}_{7}$ was found in all plants. After contamination, $\mathrm{PPO}_{6}$ was demonstrated in all plants except those having germinated in fungicide Sumi 8 (lines 16 to 18). In TMS30572, 5 isoenzymes rated $\mathrm{PPO}_{1}, \mathrm{PPO}_{3}, \mathrm{PPO}_{5}, \mathrm{PPO}_{9}$ and $\mathrm{PPO}_{11}$ were found (Figure 2). Isoenzymes $\mathrm{PPO}_{1}$ and $\mathrm{PPO}_{3}$ are present in all plants. By against, $\mathrm{PPO}_{9}$ and $\mathrm{PPO}_{11}$ were identified only in plants treated with SA (lines 10 to 12) and $\mathrm{PA}$ (lines 13 to 15 ) (Figure 2). $\mathrm{PPO}_{5}$ form is specifically appeared at $12^{\text {th }}$ Day in contaminated PC (line 3), plants elicited with SA and contaminated (lines 4 and 5), plants treated with SA and contaminated (lines 11 and 12) and plants treated with PA and contaminated at $5^{\text {th }}$ Day (Figure 2). Four isoenzymes namely $\mathrm{PPO}_{2}, \mathrm{PPO}_{4}, \mathrm{PPO}_{8}$ and $\mathrm{PPO}_{10}$ were observed in $188 / 00158$ (Figure 3). $\mathrm{PPO}_{2}$ and $\mathrm{PPO}_{4}$ are present in all plants regardless of treatment received. Isoenzymes $\mathrm{PPO}_{8}$ and $\mathrm{PPO}_{10}$ are found in most elicited and treated plants. However, some differences were observed. $\mathrm{PPO}_{8}$ was absent in plants elicited with Sumi 8 and contaminated (lines 8 and 9) as well as in plants treated with Sumi 8 and contaminated at $12^{\text {th }}$ Day (line 18). This form was also absent in PC (line1) and contaminated witnesses during 5 days (line 2). As for isoenzyme $\mathrm{PPO}_{10}$, it was detected in all treated plants except plants treated with Sumi 8 and contaminated (lines 17 and 18) and those treated with PA and contaminated at $5^{\text {th }}$ Day (line 14). In elicited plants, $\mathrm{PPO}_{10}$ was identified by the presence of AP (lines 6 and 7) and SA after 5 days of infection (line 4) 
(Figure 3). Examples of PPO isoenzymes induction were mentioned by Niranjan-Raj et al. [24], Karthiekeyan et al. [23] and, Wu and Duan [20] in bean (V. mungo) and millet (Glycine max). These authors noted the timeliness and amplification of PPO activities in resistant varieties compared to susceptible varieties. Thus, in millet, five isoenzymes were identified in resistant varieties whereas in susceptible varieties, they are four [24]. Fifth PPO has been induced during Sclerospora graminicola inoculation. In $V$. mungo, new forms were induced after treatment plants with SA and benzothiadiazole [23].

\subsection{Polyphenol Oxidases Activities}

Polyphenol oxidases (PPO) activities measured in cassava plant leaves subjected to different treatments was expressed in percentage, taking as $100 \%$, enzyme activity obtained with plants from uncontaminated medium $\left(\mathrm{M}_{0}, 0\right.$ Day) (Table 1). In response to $C$. gloeosporioides, plants from $\mathrm{M}_{0}, \mathrm{M}_{\mathrm{AS}}, \mathrm{M}_{\mathrm{AP}}$ and $\mathrm{M}_{\mathrm{S}}$ medium have reacted differently. Indeed, in $\mathrm{PC}\left(\mathrm{M}_{0}\right.$ uncontaminated), PPO activities remained constant for all cultivars during experiment. When these PC were contaminated, PPO activities increased rapidly at $5^{\text {th }}$ Day before declining towards the end of experiment. Percentage of PPO stimulation was higher among TMS30572 (39\%), average for yacé $(21 \%)$ and lower in I88/00158 (15\%) (Table $1)$. When plants were elicited and contaminated by fungi $\left(\mathrm{M}_{0 \mathrm{SA}}, \mathrm{M}_{0 \mathrm{PA}}\right.$ and $\left.\mathrm{M}_{0 \mathrm{~S}}\right)$ in the presence of PA, maximum stimulation of enzyme was 60 and $68 \%$ respectively in yacé and TMS30572. At $188 / 00158$, it was $39 \%$. In the presence of SA, value has hovered around $50 \%$ for yacé $(52 \%)$ and TMS30572 (49\%). For yacé and TMS30572, PPO activities increased rapidly before falling at $12^{\text {th }}$ Day for SA and PA (Table 1). In uncontaminated treated plants group $\left(\mathrm{M}_{\mathrm{SA}}, \mathrm{M}_{\mathrm{PA}}\right.$ and $\mathrm{M}_{\mathrm{S}}$ uncontaminated), PPO activities were well above that of non-infected PC ( $\mathrm{M}_{0}$ uncontaminated) exception of plants resulting from Sumi 8 medium (Ms) (Table 1). In this environment, Sumi 8 negatively influenced enzyme activity evolution in yacé. When treated plants were infected $\left(\mathrm{M}_{\mathrm{SA}}\right.$, $\mathrm{M}_{\mathrm{PA}}$ and $\mathrm{M}_{\mathrm{S}}$ contaminated), $\mathrm{PPO}$ activities varied among cultivars and elicitors (Table 1). Maximum stimulation of PPO exceeded $50 \%$ in all cultivars treated with SA. Greatest stimulation of enzyme was among I88/00158. It was $112 \%$. In the presence of PA, significant stimulation was achieved in TMS30572 (83\%), followed yacé (64\%). At $188 / 00158$, value was $10 \%$. For treated plants with Sumi 8, maximum stimulation of PPO did not exceed $15 \%$ (Table 1). These results show that increase of PPO isoenzymes was responsible for amplitude of their activity. In many plant tissues, increasing PPO genes in response to hormones related to defense such as salicylic acid and jasmonic acid is implicitly linked to the resistance of these pathogens [2] [11]. In cassava, induced isoenzymes identified were specific to cultivars. In contrast, intensity of reaction was more enhanced with treatment and / or contamination with $C$. gloeosporioides. Signal produced by pathogen or elicitor SA, PA or Sumi 8 was essential to trigger the synthesis and accumulation of defense gene products in treatment plants
[25] [26] [27]. Beneficial role of Sumi 8 in improving cassava defense can therefore lead to the synthesis and accumulation of phenolic compounds although PPO activities were low in the presence of the latter [10]. According to these authors, metabolic pathways leading to phenol synthesis would be induced in cassava as suggested by Rodriguez et al.[28] work. On cassava tubers, they indicated accumulation of three hydroxycoumarins which scopoletin. It had an antimicrobial function.
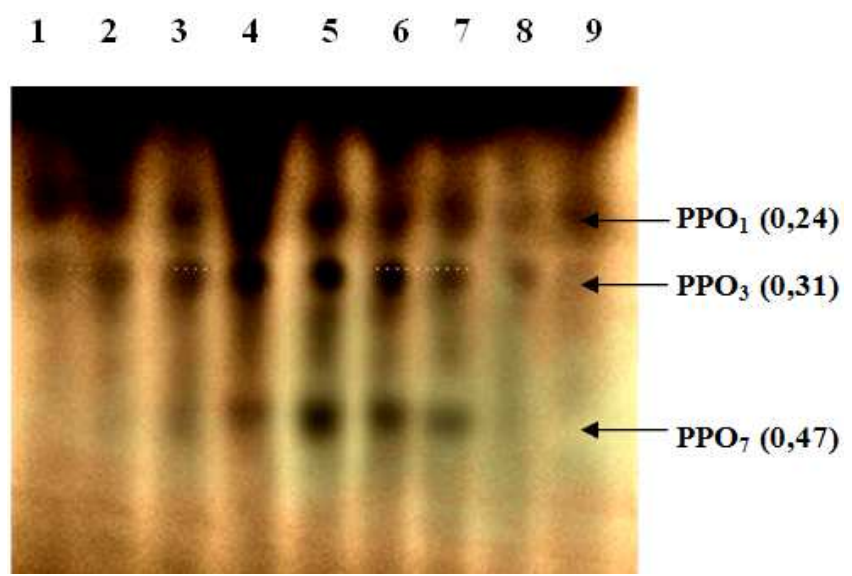

$\begin{array}{lllllllll}10 & 11 & 12 & 13 & 14 & 15 & 16 & 17 & 18\end{array}$

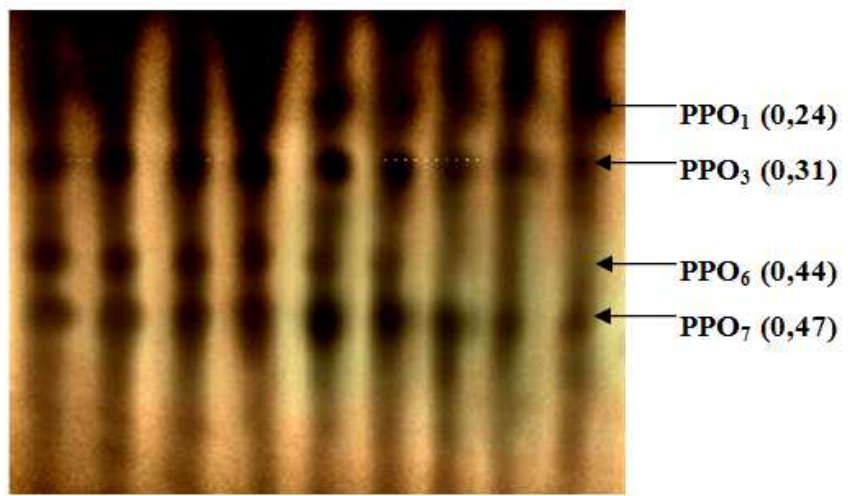

Figure 1. Native-PAGE of polyphenol oxidases extracted of cassava yacé leaves treated with salicylic acid (SA), phosphorous acid (PA) and fungicide Sumi 8 and contaminated by Colletotrichum gloeosporioides (C.gl.).

A : 1- control plant; 2- contaminated plant by C.gl at $5^{\text {th }}$ Day; 3-contamined plant by C.gl at $12^{\text {th }}$ Day; 4-elicited plant with SA and contaminated by C.gl, at $5^{\text {th }}$ Day; 5 - elicited plant with SA and contaminated by C.gl, at $12^{\text {th }}$ Day; 6elicited plant with PA and contaminated by C.gl, at $5^{\text {th }}$ Day; 7- elicited plant with PA and contaminated by C.gl, at $12^{\text {th }}$ Day; 8 - elicited plant with Sumi 8 and contaminated by C.gl, at $5^{\text {th }}$ Day; 9- elicited plant with Sumi 8 and contaminated by C.gl, at $12^{\text {th }}$ Day.

B : 10- treated plant with SA; 11- treated plant with SA and contaminated by C.gl at $5^{\text {th }}$ Day; 12-treated plant with SA and contaminated by C.gl at $12^{\text {th }}$ Day; 13-treated plant with PA; 14-treated plant with PA and contaminated by C.gl, at $5^{\text {th }}$ Day; 15 -treated plant with PA and contaminated by C.gl, at $12^{\text {th }}$ Day; 16-treated plant with Sumi 8; 17-treated plant with Sumi 8 and contaminated by C.gl, at $5^{\text {th }}$ Day; 18-treated plant with Sumi 8 and contaminated by C.gl at $12^{\text {th }}$ Day. 

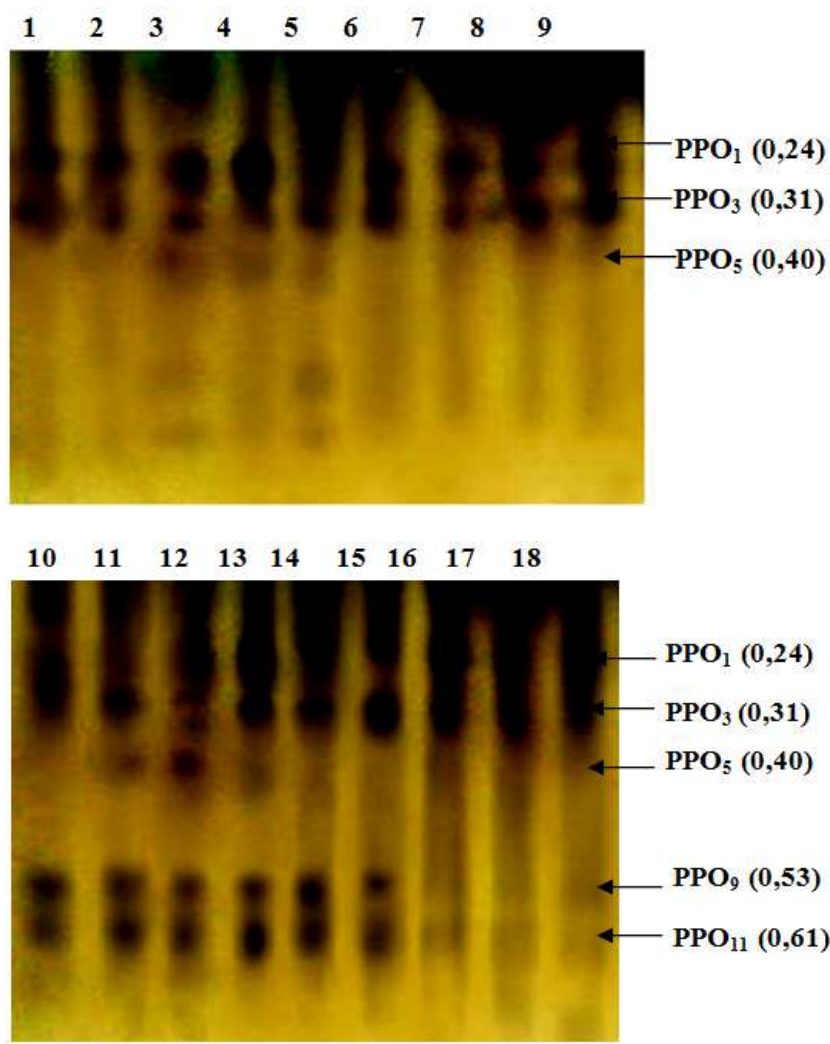

Figure 2. Native-PAGE of polyphenol oxidases extracted of cassava TMS30572 leaves treated with salicylic acid (SA), phosphorous acid (PA) and fungicide Sumi 8 and contaminated by Colletotrichum gloeosporioides (C.gl.).

A : 1- control plant; 2- contaminated plant by C.gl at $5^{\text {th }}$ Day; 3-contamined plant by C.gl at $12^{\text {th }}$ Day; 4-elicited plant with SA and contaminated by C.gl, at $5^{\text {th }}$ Day; 5 - elicited plant with SA and contaminated by C.gl, at $12^{\text {th }}$ Day; 6elicited plant with PA and contaminated by C.gl, at $5^{\text {th }}$ Day; 7- elicited plant with PA and contaminated by C.gl, at $12^{\text {th }}$ Day; 8 - elicited plant with Sumi 8 and contaminated by C.gl, at $5^{\text {th }}$ Day; 9- elicited plant with Sumi 8 and contaminated by C.gl, at $12^{\text {th }}$ Day.

B : 10- treated plant with SA; 11- treated plant with SA and contaminated by C.gl at $5^{\text {th }}$ Day; 12 -treated plant with SA and contaminated by C.gl at $12^{\text {th }}$ Day; 13-treated plant with PA; 14-treated plant with PA and contaminated by C.gl, at $5^{\text {th }}$ Day; 15 -treated plant with PA and contaminated by C.gl, at $12^{\text {th }}$ Day; 16-treated plant with Sumi 8; 17-treated plant with Sumi 8 and contaminated by C.gl, at $5^{\text {th }}$ Day; 18 -treated plant with Sumi 8 and contaminated by C.gl at $12^{\text {th }}$ Day.
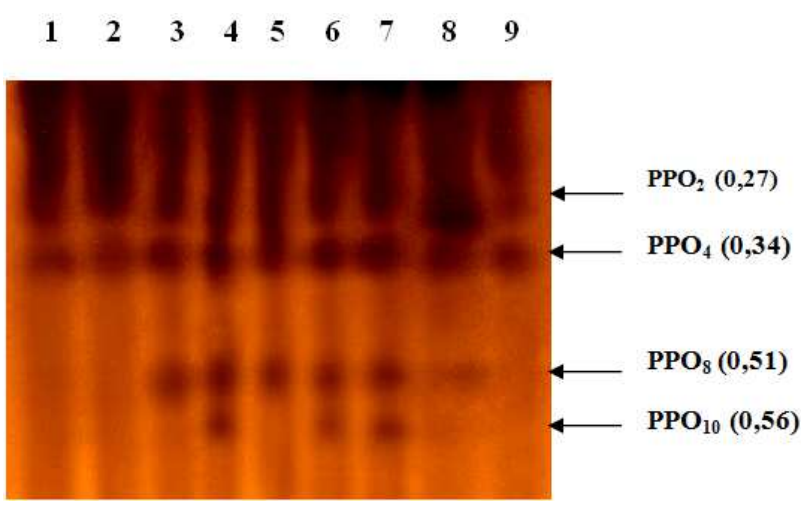

$\begin{array}{lllllllll}10 & 11 & 12 & 13 & 14 & 15 & 16 & 17 & 18\end{array}$

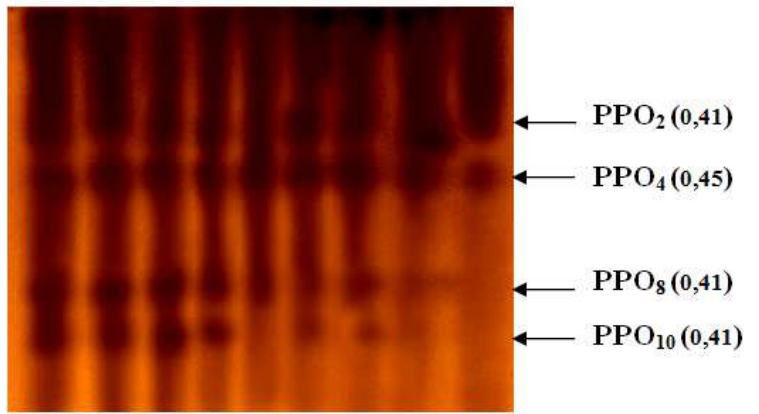

Figure 3. Native-PAGE of polyphenol oxidases extracted of cassava I88/00158 leaves treated with salicylic acid (SA), phosphorous acid (PA) and fungicide Sumi 8 and contaminated by Colletotrichum gloeosporioides (C.gl.).

A : 1- control plant; 2- contaminated plant by C.gl at $5^{\text {th }}$ Day; 3-contamined plant by C.gl at $12^{\text {th }}$ Day; 4-elicited plant with SA and contaminated by C.gl, at $5^{\text {th }}$ Day; 5 - elicited plant with SA and contaminated by C.gl, at $12^{\text {th }}$ Day; 6elicited plant with PA and contaminated by C.gl, at $5^{\text {th }}$ Day; 7- elicited plant with PA and contaminated by C.gl, at $12^{\text {th }}$ Day; 8 - elicited plant with Sumi 8 and contaminated by C.gl, at $5^{\text {th }}$ Day; 9- elicited plant with Sumi 8 and contaminated by C.gl, at $12^{\text {th }}$ Day.

B : 10- treated plant with SA; 11- treated plant with SA and contaminated by C.gl at $5^{\text {th }}$ Day; 12-treated plant with SA and contaminated by C.gl at $12^{\text {th }}$ Day; 13-treated plant with PA; 14-treated plant with PA and contaminated by C.gl, at $5^{\text {th }}$ Day; 15 -treated plant with PA and contaminated by C.gl, at $12^{\text {th }}$ Day; 16-treated plant with Sumi 8; 17-treated plant with Sumi 8 and contaminated by C.gl, at $5^{\text {th }}$ Day; 18-treated plant with Sumi 8 and contaminated by C.gl at $12^{\text {th }}$ Day.

Table 1. Effects of salicylic acid, phosphorous acid and fungicide Sumi 8 on Colletotrichum gloeosporioïdes (cm) propagation inside cassava stem at $12^{\text {th }}$ Day after plant contamination.

\begin{tabular}{|c|c|c|c|c|c|c|c|}
\hline \multirow[t]{3}{*}{$\begin{array}{l}\text { Cassava } \\
\text { cultivars }\end{array}$} & \multicolumn{7}{|c|}{ Elicitors } \\
\hline & \multicolumn{3}{|c|}{ Salicylic acid } & \multicolumn{2}{|c|}{ Phosphorous acid } & \multicolumn{2}{|c|}{ Sumi 8} \\
\hline & PC & PE & PT & $\mathbf{P E}$ & PT & $\mathbf{P E}$ & PT \\
\hline \multirow[t]{2}{*}{ yacé } & $3,63 \mathrm{a} 1$ & $1,17 \mathrm{a} 2$ & $0,10 \mathrm{a} 3$ & $1,40 \mathrm{a} 2$ & $0,10 \mathrm{a} 3$ & $1,90 \mathrm{a} 2$ & $0,10 \mathrm{a} 3$ \\
\hline & $\pm 0,85$ & $\pm 0,35$ & \pm 0 & $\pm 0,75$ & \pm 0 & $\pm 0,87$ & \pm 0 \\
\hline \multirow[t]{2}{*}{ bonoua2 } & 3,30a1 & $1,03 \mathrm{a} 2$ & $0,13 \mathrm{a} 3$ & $1,10 \mathrm{a} 2$ & $0,10 \mathrm{a} 3$ & $1,70 \mathrm{a} 2$ & $0,10 \mathrm{a} 3$ \\
\hline & $\pm 0,75$ & $\pm 0,11$ & $\pm 0,05$ & $\pm 0,30$ & \pm 0 & $\pm 0,78$ & \pm 0 \\
\hline \multirow[t]{2}{*}{ TMS30572 } & $1,40 \mathrm{~b} 1$ & $0,77 \mathrm{a} 2$ & $0,17 \mathrm{a} 3$ & $1,17 \mathrm{a} 12$ & $0,10 \mathrm{a} 3$ & $1,50 \mathrm{a} 1$ & $0,10 \mathrm{a} 3$ \\
\hline & $\pm 0,62$ & $\pm 0,15$ & $\pm 0,05$ & $\pm 0,05$ & \pm 0 & $\pm 0,10$ & \pm 0 \\
\hline \multirow[t]{2}{*}{ I88/00158 } & $3,03 \mathrm{a} 1$ & $3,00 \mathrm{~b} 1$ & $0,20 \mathrm{a} 2$ & $2,53 \mathrm{~b} 1$ & $0,87 \mathrm{~b} 3$ & $0,93 \mathrm{a} 3$ & $0,10 \mathrm{a} 2$ \\
\hline & $\pm 0,20$ & $\pm 0,45$ & $\pm 0,10$ & $\pm 0,51$ & $\pm 0,80$ & $\pm 0,15$ & \pm 0 \\
\hline
\end{tabular}

PC: control plant; PE: elicited plant; PT: treated plant; each value is the average of 3 replicates \pm standard deviation.

For each column, means followed a single alphabetical letter are not statistically different for a threshold of $5 \%$ according to the test Dancun.

For each line, means followed by the same figure not statistically different for a threshold of 5\% according to the test Dancun. 
Table 2. Activities of polyphenol oxidases (\%.) extracted of cassava leaves after treatment with salicylic acid (SA), phosphorous acid (PA) or fungicide Sumi 8 and/or inoculated by Colletotrichum gloeosporioides at $0,5^{\text {th }}$ and $12^{\text {th }}$ Days after plant contamination.

\begin{tabular}{|c|c|c|c|c|c|c|c|c|c|c|c|c|}
\hline \multirow{4}{*}{$\begin{array}{l}\text { Cassava } \\
\text { cultivars }\end{array}$} & & \multicolumn{11}{|c|}{ Culture medium } \\
\hline & & \multicolumn{4}{|c|}{ Uncontaminated } & \multicolumn{7}{|c|}{ Contaminated } \\
\hline & & PC & PT & & & PC & PE & & & PT & & \\
\hline & & M0 & MSA & MPA & MS & M0 & MOSA & MOPA & MOS & MSA & MPA & MS \\
\hline \multirow{4}{*}{ yacé } & $0 \mathrm{j}$ & 100 & 108 & 121 & 85 & 100 & 100 & 100 & 100 & 108 & 121 & 85 \\
\hline & $5 \mathrm{j}$ & 100 & 108 & 121 & 85 & 121 & 152 & 161 & 84 & 161 & 164 & 75 \\
\hline & $12 \mathrm{j}$ & 100 & 108 & 121 & 85 & 113 & 129 & 150 & 105 & 139 & 134 & 91 \\
\hline & $0 \mathrm{j}$ & 100 & 115 & 104 & 101 & 100 & 100 & 100 & 100 & 115 & 104 & 101 \\
\hline \multirow[t]{3}{*}{ I88/ } & $5 \mathrm{j}$ & 100 & 115 & 104 & 101 & 115 & 138 & 128 & 132 & 212 & 107 & 107 \\
\hline & $12 \mathrm{j}$ & 100 & 115 & 104 & 101 & 107 & 113 & 139 & 127 & 141 & 110 & 105 \\
\hline & $0 \mathrm{j}$ & 100 & 106 & 115 & 101 & 100 & 100 & 100 & 100 & 106 & 115 & 101 \\
\hline \multirow[t]{2}{*}{ TMS30 } & $5 \mathrm{j}$ & 100 & 106 & 115 & 101 & 139 & 149 & 168 & 109 & 174 & 183 & 115 \\
\hline & $12 \mathrm{j}$ & 100 & 106 & 115 & 101 & 130 & 140 & 153 & 105 & 116 & 164 & 109 \\
\hline
\end{tabular}

PC: control plant; PE: elicited plant; PT: treated plant; SA: salicylic acid, PA: phosphorous acid, TMS30: TMS30572, I88/: I88/00158. M 0 : nutrient medium; $\mathrm{M}_{\mathrm{SA}}, \mathrm{M}_{\mathrm{PA}}$ and $\mathrm{M}_{\mathrm{S}}$ : nutrient medium respectively containing SA, PA and Sumi $8 ; \mathrm{M}_{0 \mathrm{SA}}, \mathrm{M}_{0 \mathrm{PA}}$ and $\mathrm{M}_{0 \mathrm{~S}}$ : germination in the nutrient medium and then transfer in the nutrient medium supplemented with SA, PA or Sumi 8. 100\%=1247,61 (yacé); 1130,83(TMS30572) and 930,83 (I88/00158) $\Delta D O$ min $^{-1} \mathrm{mg}^{-1} \mathrm{prot}_{\text {. }}$

\section{Conclusion}

This work aims to investigate alternatives to use of pesticides as the only means of struggle against cassava enemies. Results of this study have demonstrated that several PPO isoenzymes were induced after different treatments with elicitors SA, PA and Sumi 8. SA and PA involved more amplification of PPO activities. By cons, fungicide Sumi 8 inhibits the activity of the enzyme. But it also improves the strength of cassava anthracnose.

\section{References}

[1] Thipyapong P, Stout MJ and Attajarusit J (2007). Functional analysis of polyphenol oxidases by antisense/sense technology. Molecules 12: 1569-1594.

[2] Mayer AM (2006). Polyphenol oxidases in plants and fungi: going places ? A review. Phytochemistry 67(21): 2318-2331.

[3] Constabel C.P. and R. Barbehenn. 2008. Defensive roles of polyphenol oxidase in plants. In A. Schaller (ed.), Induced Plant Resistance to Herbivory. Springer, New York.

[4] Shahidi F and Naczk M (1995). Phenolic compounds in fruits and Vegetables. In Food phenolics: Sources, Chemistry, Effects and Applications; Technomic Publishing: Lancaster, PA 75-107.

[5] Weir TL, Park SW and Vivanco JM (2004). Biochemical and physiological mechanisms mediated by allelochemicals. Current Opinion in Plant Biology 7(4):472-479.

[6] Gyanendra kumar Rai, Rajesh kumar, Singh J, Rai P.K. and Rai S.K (2011). Peroxidase, polyphenol oxidase activity, protein profile and phenolic content in tomato cultivars tolerant and susceptible to Fusarium oxsyporum f.sp.lycopersici. Pakistan Journal of Botany 43(6): 2987-2990

[7] Ogawa D, Nakajima N, Sano T, Tomaoki M, Aono M, Kubo A, Kanna M, Ioki M, Kamada H and Saji H (2005). Salicylic acid accumulation under $\mathrm{O}_{3}$ exposure is regulated by ethylene in tobacco plants. Plant Cell Physiology 46: 1062-1072.
[8] Ojha S and Chatterjee NC (2012). Induction of resistance in tomato plants against Fusarium oxysporium f. sp. Lycopersici mediated through salicylic acid and trichoderma harzianum. Journal of Plant Protection Research 52(2): 220-225.

[9] Dogbo DO, Békro-Mamyrbekova JA, Békro Y-A, Sié RS, Gogbeu SJ and Traoré A (2008). Influence de l'acide salicylique sur la synthèse de la phénylalanine ammonia-lyase, des polyphénoloxydases et l'accumulation des composes phénoliques chez le manioc (Manihot esculenta Crantz). Science \& Nature 5(1):1-13.

[10] Gogbeu S.J, Dogbo D.O, Zohouri G.P, N'zue B, Bekro Y-A and Békro-Mamyrbekova J.A (2012). Induction of polyphenol oxidases activities and phenolic compounds accumulation in cells and plants elicited of cassava (Manihot esculenta Crantz). Journal of Scientific Research and Reviews 1(1): 7 - 14.

[11] Flurkey W.H, Inlow J.K. (2008). Proteolytic processing of polyphenol oxidase from plants and fungi. Journal of Inorganic Biochemistry 102 : 2160-2170

[12] FAO (2010). Statistical databases. Rome (Italy).http://www.fao.org

[13] Prusky D, Freeman S and Dickman MB (2000). Colletotrichum: Host specificity, pathology and host-pathogen interaction. St Paul USA: APS Press. 400 p.

[14] Buhot N (2003). Rôle des élicitines et des protéines de transfert de lipides dans l'induction de la résistance des plantes à leurs agents pathogène. Thèse de Doctorat unique. Université de Bourgogne $278 \mathrm{p}$

[15] Thakore Y (2006). The biopesticide market for global agricultural use. Industrial Biotechnology 2(3): 294-208.

[16] Makambila (1983). Epidémiologie de l'anthracnose du manioc. In : Plantes-racines tropicales : culture et emplois en Afrique, actes $\mathrm{du}$ second symposium triennal de la société internationale pour les plantes-racines tropicales, Douala, Cameroun, 75-80.

[17] Gogbeu S.J, Sekou D, Kouakou K.J, Dogbo D.O and Bekro YA (2015). Improvement of Cassava resistance to Colletotrichum gloeosporioïdes by Salicylic acid, Phosphorous acid and Fungicide Sumi 8. International Journal of Current Microbiology and Applied Sciences 4(3): 854-865 
[18] Gogbeu S.J, Dogbo D.O, Gonety T.J, N'zue B, Zohouri G.P and Boka A (2011). Study of some characteristics of soluble polyphenol oxidases from six cultivars callus of cassava (Manihot esculenta Crantz). Journal of Animal and Plant Sciences, 9(3): 1169- 1179

[19] Laemmli UK (1970). Cleavage of structural protein during the assembly of the head of bacteriophage T4. Nature 227:680685 .

[20] Wu HY and Duan YX (2011). Defense response of soybean (Glycine max) to soybean cyst nematode (Heterodera glycines) race3 infection. The Journal of Animal and Plant Sciences 21(2): $165-170$

[21] Bradford MM (1976). A rapid and sensitive method for the quantification of microgram quantities of protein utilizing the principle of protein binding. Analytical Biochemistry 72: 248254

[22] Reuveni R and Reuveni M (1998). Foliar-fertilizer therapy - a concept in integrated pest management. Crop Protection 17(2): 111-118.

[23] Karthikeyan G, Doraisamy S and Rabindran R (2009). Induction of systemic resistance in blackgram (Vigna mungo) against urdbean leaf crinkle virus by chemicals. Archives of Phytopathology and Plant Protection 42(1):1-15
[24] Niranjan-Raj S, Sarosh BR and Shetty HS (2006). Induction and accumulation of polyphenol oxidases activities as implicated in development of resistance against pearl millet downy mildew disease. Functional Plant Biology 33:563-571

[25] Conrath U, Beckers GJM, Flors V, Garcia-Augustin P, Jakab G Mauch F, Newman MA, Pieterse CMJ, Poinssot B, Pozo MJ, Pugin A, Schaffrath U, Ton J, Wendehenne D, Zimmerle L, Mauch-Mauch B and Grp PAP (2006). Priming: Getting ready for battle. Molecular Plant- Microbe Interctactions 19(10):1062-1071

[26] Kishimoto K, Matsui K, Ozawa R and Takabayashi J (2006). ETR1-, JAR1-and PAD2-dependent signaling pathways are involved in C6-aldehyde-induced defense responses of Arabidopsis. Plant Science 171(3): 415-423.

[27] Ton J, D'Alessandro M, Jourdie V, Jakab G, Karlen D, Held M, Mauch-Mani B and Turlings TCJ (2007). Priming by airborne signals boosts direct and indirect resistance in maize. Plant Journal 49(1):16-26.

[28] Rodriguez MX, Buschmann H, Iglesias C and Beeching JR (2000). Production of antimicrobial compounds in cassava (Manihot esculenta Crantz) roots during post-harvest physiological deterioration. In: Carvalho LJCB, Thro AM, Vilarinhos AD, eds. Cassava Biotechnology. IV ${ }^{\text {th }}$ International Scientific Meeting Cassava Biotechnology Network. Embrapa, Brasilia 320-328 